\title{
Morphology and anatomy of leaf miners in two species of Commelinaceae (Commelina diffusa Burm. f. and Floscopa glabrata (Kunth) Hassk)
}

\author{
Paula Maria Elb ${ }^{1,2,3}$, Gladys Flávia Melo-de-Pinna ${ }^{2}$ and Nanuza Luiza de Menezes ${ }^{2}$
}

Recebido em 29/09/2008. Aceito em 7/12/2009

RESUMO - (Morfologia e anatomia de minas foliares em duas espécies de Commelinaceae Commelina diffusa Burm. f. e Floscopa glabrata (Kunth) Hassk)). Existem poucos relatos na literatura sobre anatomia de plantas parasitadas por agentes minadores, os quais promovem escavações ou caminhos através do consumo dos tecidos internos das plantas por larvas de diversos insetos. A proposta deste trabalho foi analisar anatomicamente a ocorrência de minas foliares em Commelina diffusa (planta cosmopolita) e Floscopa glabrata (planta anfíbia) causadas por espécies de larvas endofitófagas de dípteros, pertencentes a duas famílias: Agromyzidae e Chironomidae. O local onde as plantas foram coletas está sujeito a inundações sazonais, e as duas espécies foram submetidas às mesmas condições climáticas. Em Commelina diffusa foram encontradas larvas da família Agromyzidae e, em Floscopa glabrata observaram-se três exuvias cefálicas de Chironomidae. Os dados anatômicos revelaram que os minadores se alimentaram apenas dos tecidos parenquimáticos do mesofilo, formando minas lineares. Além disso, notou-se que a epiderme e as unidades vasculares de porte médio foram mantidos intactos em ambas as espécies, não apresentando alterações estruturais, como a neoformação de tecidos.

Palavras-chave: anatomia vegetal, minadores, planta anfíbia, Chironomidae, Agromyzidae

\begin{abstract}
Morphology and anatomy of leaf miners in two species of Commelinaceae (Commelina diffusa Burm. f. and Floscopa glabrata (Kunth) Hassk)). In specialized literature, reports on anatomy of miners in host plants are few in number. These agents trigger excavations, or paths, by consumption of plant inner tissues by larvae of several insects. The aim of this work was to investigate leaf miner occurrence in Commelina diffusa (a cosmopolitan plant) and Floscopa glabrata (an amphibious plant) using anatomical techniques. The place where the plants were collected is subjected to seasonal floods, consequently both the species were exposed to the same weather conditions and seasonal floods. This study showed that members of Agromyzidae and Chironomidae families, which are Diptera endophytophagous larvae types, were responsible for the tunnels. Moreover, in Commelina diffusa Agromyzidae larvae were found, while in Floscopa glabrata three Chironomidae cephalic exuviae were found. The miners, as can be seen from anatomical studies, used only mesophyll parenchyma tissues for feeding, causing the formation of linear mines. In addition, in both the species, the epidermis and the medium-sized vascular units were kept intact, showing no structural modification, such as neoformation of tissues.
\end{abstract}

Key words: plant anatomy, miners, amphibious plant, Chironomidae, Agromyzidae

\section{Introduction}

The miner and plant relationship may have arisen 275 million years ago being, probably, a beneficial interaction to the miner, inasmuch as the host plant offers food and shelter to the miner during the larval period of its life cycle (Labandeira 1998).

Several earlier reports show that there are about 10,000 described species of leaf miners, and these miners occur in 51 families of holometabolous insects, which are insects with complete metamorphosis. These families are part of some well known orders, such as, Coleoptera, Diptera, Lepidoptera, and Hymenoptera (Needham et al. 1928, Hering 1951, Bickel 1982, Brown 1982, Hespenheide 1991).

Among the current plant species, there are many reports on miners in a large number of families including Amaranthaceae, Asteraceae, Boraginaceae, Chenopodiaceae, Clusiaceae, Commelinaceae, Convolvulaceae, Dipsacaceae, Lamiaceae, Mytaceae, Poaceae, Rubiaceae, and Rutaceae (Hering 1951; Melo-de-Pinna et al. 2002; Almeida-Cortez \& Melo-de-Pinna 2006; Santos et al. 2006). Santos et al. (2006) recently showed the occurrence of dipteran miners in Commelinaceae and five more families of angiosperms, and Commelina diffusa was the only representative of Commelinaceae. In addition, the authors found 81 larvae and 43 pupae of Liriomyza commelinae (Agromyzidae) in the Commelinaceae member. However, an anatomical description of the mines was not the main scope of their work, and this is still an aspect without detailed information in the Commelinaceae representatives.

The aim of this work is to investigate leaf miner occurrence in Commelina diffusa Burm. f. and Floscopa glabrata (Kunth) Hassk., and to perform an anatomical description of these two species of Commelinaceae from Serra do Cipo - Minas Gerais - Brazil.

\section{Experimental}

Whole plants of Commelina diffusa Burm. f. and Floscopa glabrata (Kunth) Hassk. were collected in winter (dry season) at Brauna Stream shores, which is located in Serra do Cipo National Park, Santana do Riacho, Minas Gerais, Brazil (19 18' 03,9"S, 4336' 04,1"W; 1046 m).

After visual field observation of a population of two species, mined leaves and non-mined leaves were taken from plants of different samples for anatomical studies and three sample/species were analyzed. Exsiccatae were made using part of the colleted material and these were deposited, under numbers (Elbl et al. 01) Floscopa glabrata and (Elbl et al. 04) Commelina diffusa, in Herbarium SPF University of Sao

\footnotetext{
Universidade de São Paulo, Instituto de Biociências, Programa de Pós-graduação em Ciências Biológicas (Botânica), São Paulo, SP, Brasil

2 Universidade de São Paulo, Departamento de Botânica, Laboratório de Anatomia Vegetal, São Paulo, SP, Brasil

3 Autor para correspondência: paulaelbl@usp.br
} 
Paulo, Bioscience Institute. These leaves were fixed in FAA 50 (formaldehyde, acetic acid and ethanol 50\%, 1:1:18 v/v) for 48 hours (Johansen 1940), and then immersed in ethanol $50 \%$ for 24 hours. Afterwards, some regions of leaves (mined and non-mined) were selected, cut, dehydrated in ethanol series and included in paraffin (Ruzin 1999). After inclusion in paraffin, the blocks were sectioned in series each $12 \mu \mathrm{m}$ thick, using a Leica RM 2145 rotary microtome. Finally, the sections were stained with astra blue and safranin $(9: 1)$, according to Kraus et al. (1998) and the slides were secured by sealing the cover slips with Canadian balsam.

Moreover, entire mined leaves were cleared according to Foster (1950) and stained with safranin 1\%; in this case, the slides were secured by sealing the cover slides with Canadian balsam. All images were obtained using a DMLB Leica optical microscope and were analyzed using the Leica software IM50.

\section{Results and discussion}

The site where plants were collected is seasonally flooded. During summer, which is the wet season, the shores of the stream tend to be covered by water. In winter, the period in which samples were collected, the water volume of the stream is lower than in other seasons, and, as a result, the shores are dry.

Floscopa glabrata (Kunth) Hassk. is considered to be an amphibious plant (Pott \& Pott 2000), and Faden \& Hunt (1991) stated that this species is found in aquatic habits. Commelina diffusa Burm. f. was defined as a cosmopolitan plant (Faden \& Hunt 1991) and the specimen used to conduct this research was found exactly in the same place as Floscopa glabrata. Consequently, both species were exposed to the same weather conditions and seasonal floods.

Floscopa glabrata and Commelina diffusa have simple leaves, glabrous and with parallel venation (Figs. 1-4). The

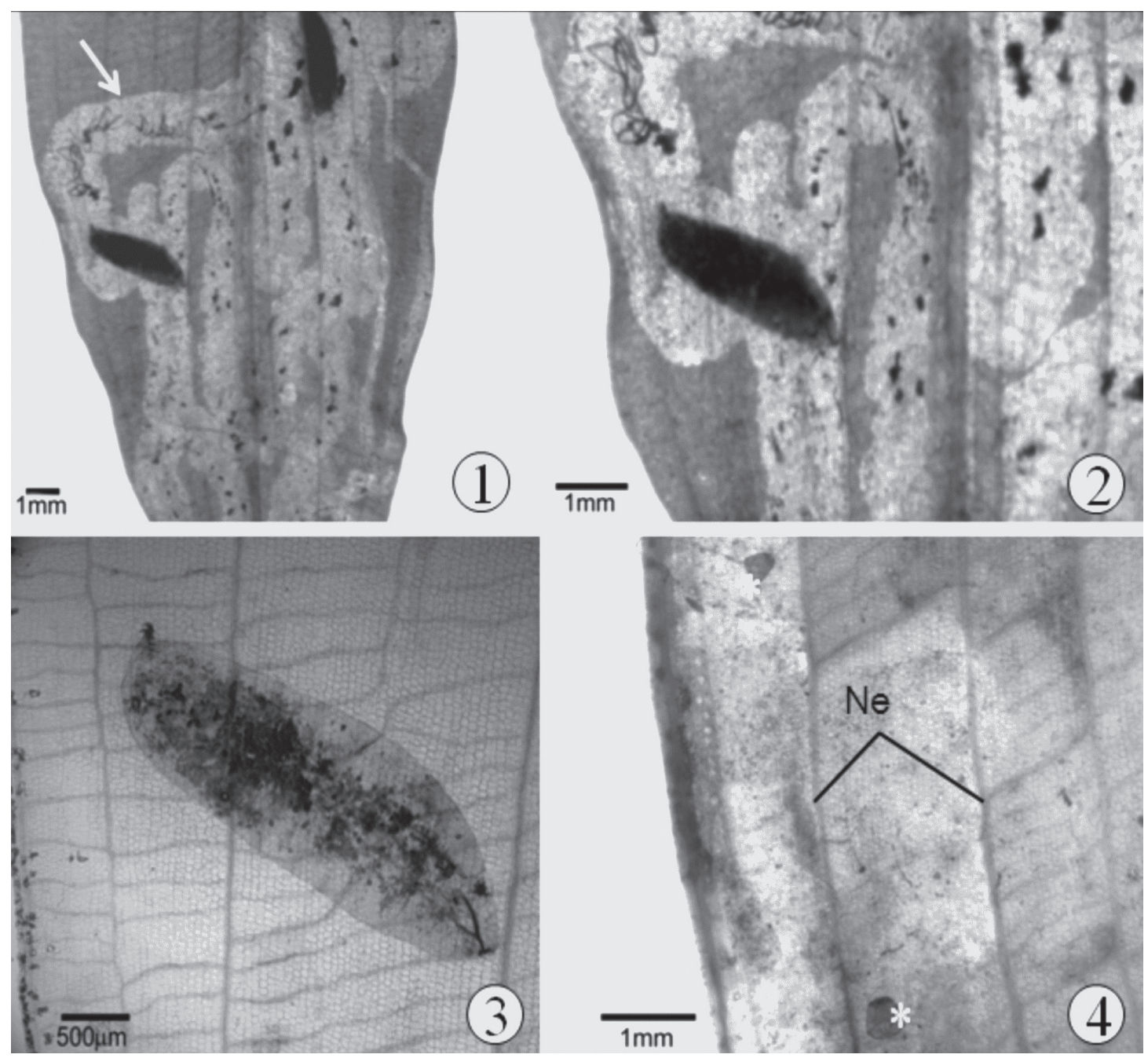

Figures 1-4. Mine leaves of Commelina diffusa Burm. f. and Floscopa glabrata (Kunth) Hassk. (Commelinaceae) from cleared material. 1-3. Larva of Agromyzidae in leaf of $C$. diffusa Burm. f.. Note the linear path (arrow) done by the miner. 3. Detail of Agromyzidae larva inside the leaf tissue. 4. Observe the head-capsules of Chironomidae miner (asterisk) inside of mesophyll of F. glabrata (Kunth) Hassk.. (Ne: parallel venation). 
miner agents observed in leaves of both species were dipterous. In Floscopa glabrata the miner was a member of Chironomidae, while in Commelina diffusa it was a member of Agromyzidae. Santos et al. (2006) also described the occurrence of larvae and pupae of Agromyzidae member (Liriomyza commeliae) in Commelina diffusa. The Agromyzidae-leaf relationship is well known and the larval phase of these insects is generally associated with plants (Stehr 1991). On the other hand, dipterous from Chironomidae has larval and pupa phases on water, and also, there is little research on interaction of Chironomidae and aquatic plants (Berg 1991).

The mines are empty tunnels triggered by miner action in the plant tissue and, according to the way they spread in the leaf, they can be classified as two principal kinds: linear and blotch (Needham et al. 1928). According to Needham et al. (1928), linear mines are formed when the larva tunnels straight ahead through the parenchyma, and if the course taken is winding they are called serpentine mines. Blotch mines are formed when the larva excavates a broad patch and may assume several shapes, such as circular, oblong, lobed, etc. Furthermore, Hering (1951) described an intermediate example; in this case the miner starts following a linear pattern, and then expands itself making a blotch. The mines in both species analyzed in this research are linear, and form real serpentines (Figs. 1-4). Earlier reports showed similar characteristics in other plant species, for instance, Richterago riparia Roque (Asteraceae) (Melo-de-Pinna et al. 2002) and Vismia guianensis (Aubl.) Choisy (Clusiaceae) (AlmeidaCortez \& Melo-de-Pinna 2006).

In the transverse sections (Figs. 5-8) the non-mined leaves of both the species have a single layer of epidermis, formed by large cells with thin walls. This layer is a water-storage tissue, and due to this fact was described as a succulent surface layer by Solereder \& Meyer (1929), The sections also showed stomata located in the same level as the epidermal cells and distributed on both faces of the epidermis. The vascular units are distributed in the middle region of mesophyll, surrounded by the endodermis (external bundle sheath) and the pericycle (internal bundle sheath), the latter being formed by non-lignin cells (Fig. 6 and 8).

Figs. 9-10 show the spot entrance of miner on the adaxial surface in both the species. In transverse sections of leaves of
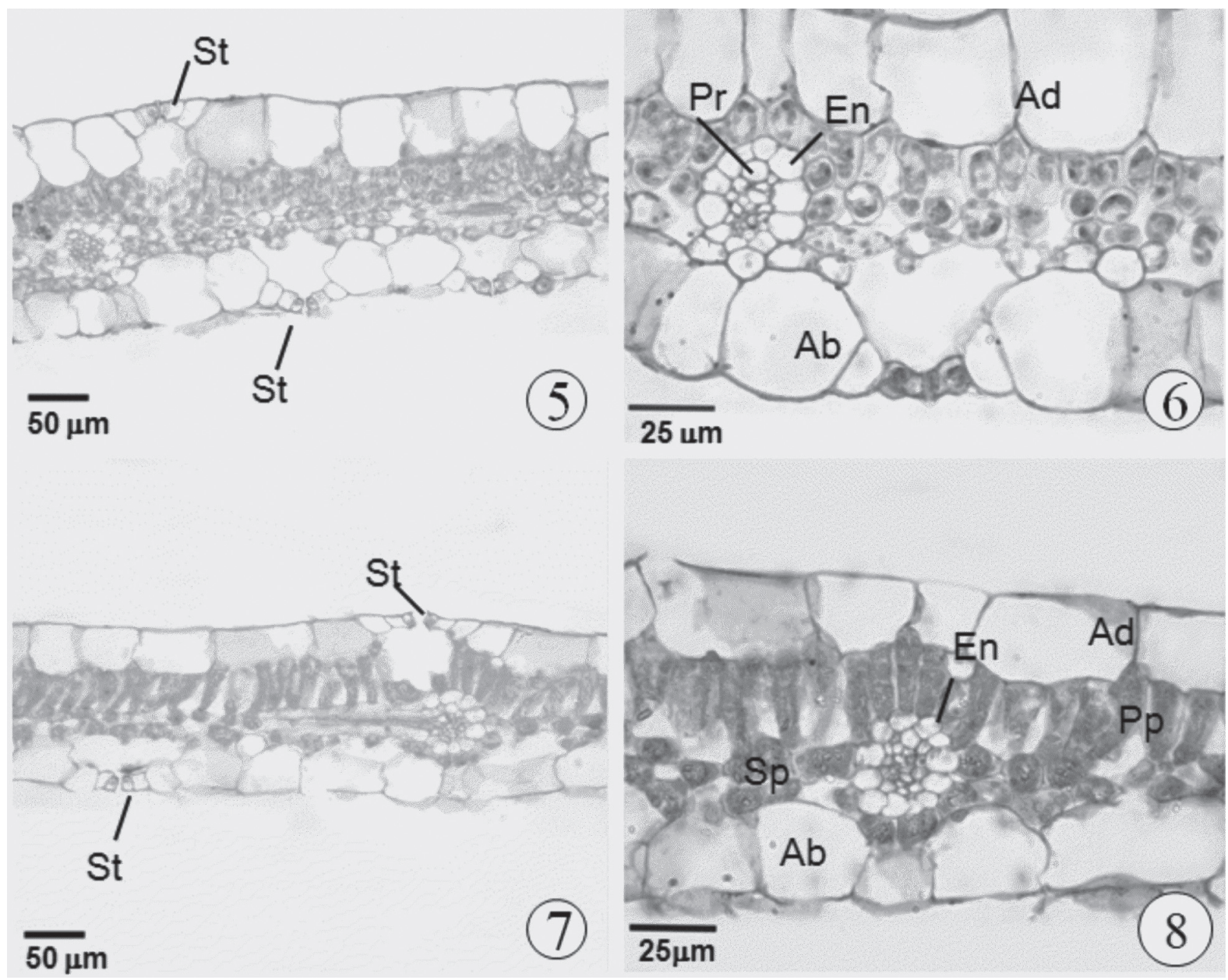

Figures 5-8. Transverse sections of non-mined leaves of Floscopa glabrata (Kunth) Hassk. (Figs.5-6) and Commelina diffusa Burm. f. (Figs.7-8). (Ab: abaxial surface of epidermis, Ad: adaxial surface of epidermis, En: endodermis, Sp: spongy parenchyma, Pp: palisade parenchyma, Pr: pericycle, St: stomata). 
Floscopa glabrata (Figs. 11 and 13) and Commelina diffusa (Figs. 12 and 14) were observed that the mine is formed by consumption of parenchyma tissues of mesophyll, and, during tunnel formation, the miner consumes both palisade and spongy parenchyma; on the other hand, the epidermis and vascular tissue remain intact (Figs. 11-14). This is independent of miner or plant groups, and the epidermis is considered by some authors as a physical protection for the larvae (Hering 1951; Melo-dePinna et al. 2002; Almeida-Cortez \& Melo-de-Pinna 2006).

Weis \& Berenbaum (1989) reported that miners do not form new tissues and this is the difference between the two types of endophytofagous (miner insects and insects that form galls). In many mines Mani (1964) reported that plant tissue remains unchanged (without formation of new tissues), but in some cases new tissues are formed near the vascular tissue. According to the author, this tissue formation is a consequence of mechanical features without a specific relation to the miner. The lack of formation of new tissues in mines was corroborated in this study and others authors described these characteristics in species of Asteraceae (Melo-de-Pinna et al. 2002) and Clusiaceae (Almeida-Cortez \& Melo-de-Pinna 2006). Morphological and anatomical studies are therefore fundamental to a better understanding of these structures associated with biological observation of miners.

Another observation revealed by Melo-de-Pinna et al. (2002) is the consumption of small sectors of the vascular tissue in Richterago riparia. According to the authors of the present research there is a possible relationship between the presence of lignin in pericycle and xylem cells, and the development phase of mouth parts of larvae. Although the endodermis and pericycle are constituted by non-lignin cells, the miner kept the medium-sized vascular unit untouched (Fig.
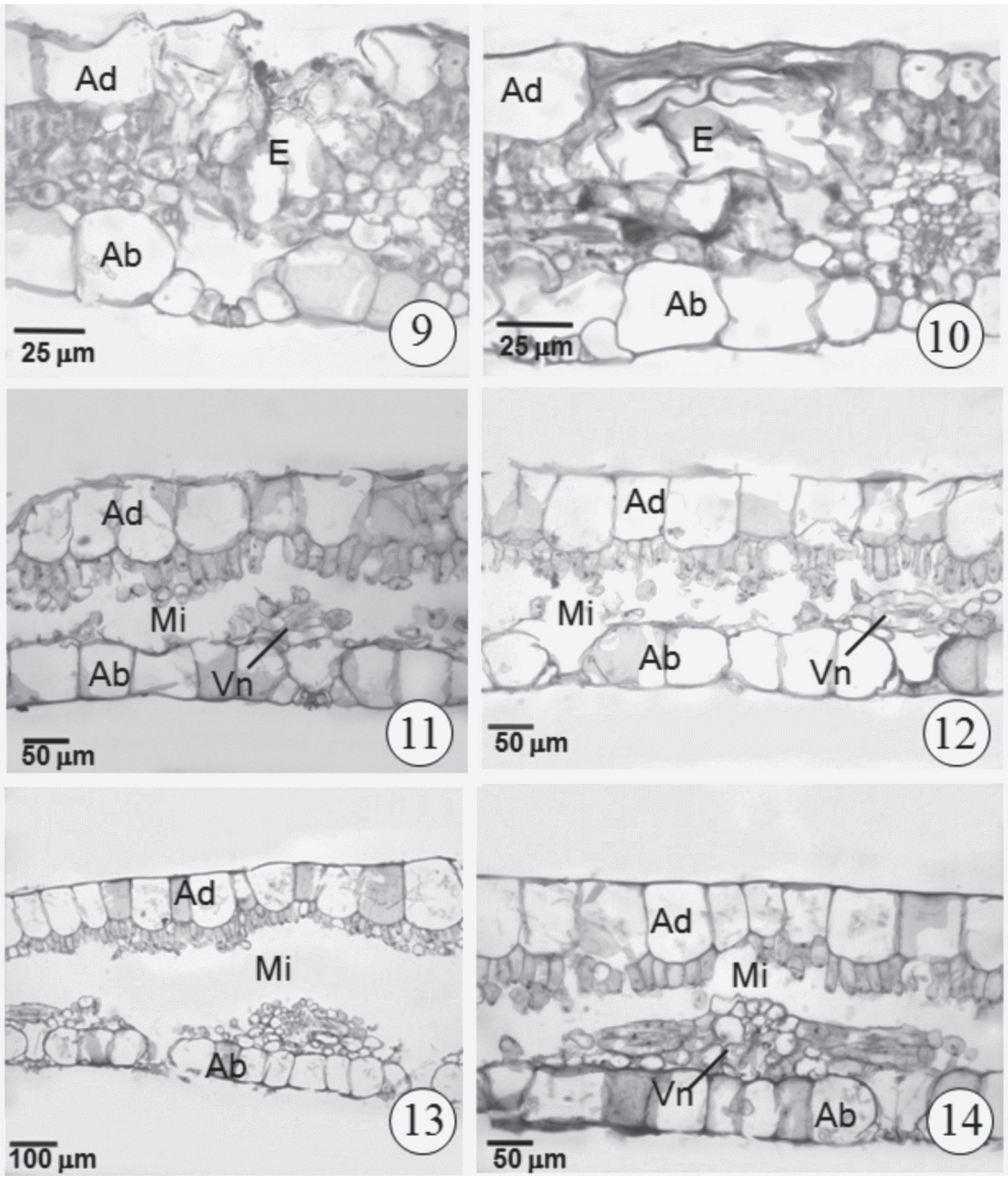

Figures 9-14. Transverse sections of mined leaves of Floscopa glabrata(Kunth) Hassk. (column on the left) and Commelina diffusa Burm. f. (column on the right). 9-10. Spot entrance (E) of miner. 11-12. Mine (Mi) formed by consumption of parenchyma tissues. Note the vascular unit (Vn) untouched (Fig.11-12 and 14). (Ab: abaxial surface of epidermis, Ad: adaxial surface of epidermis). 
14). Another common characteristic of miners is the fact that the epidermis is kept unaltered, and this is independent of miner or plant groups; in addition, the epidermis is considered by several authors as a physical protection for the larvae.

In Floscopa glabrata, at the same leaf, three headcapsules with different sizes were found; these head-capsules are probably due to a series of larval stages or instars, and two of these capsules are shown in Fig. 4. In comparison to the larvae found in Commelina diffusa, the presence of these capsules also indicates a more advanced development stage. In addition, in Floscopa glabrata there is no modification in the feeding behavior of the miner.

The high susceptibility of leaf miner to parasitoids has been attributed to low larval mobility, associated with high miner visibility (Hawkins 1994). There are several reports on mine occurrence promoted by Diptera, and many of them described species of Agromyzidae as a host of Hymenoptera (Jervis \& Kidd 1986; Abe et al. 2005; Abe 2006; Tran et al. 2007; Xu et al. 2007). In contrast, no evidence of the endoparasite Hymenoptera was observed.

Salvo and Valladares (2004) agreed on the influence of mine shape in its vulnerability to parasitoids and stated that host (miners) in blotch mines showed lower parasitism rates in comparison to linear mines.

In conclusion, the results reported in this paper indicate that the mines in both the species analyzed are linear, form real serpentines by consumption of parenchyma tissues of mesophyll, as stated in the literature (Mani 1964; Melo-de-Pinna et al. 2002; Almeida-Cortez \& Melo-de-Pinna 2006). Low larval mobility, associated with high miner visibility, makes the larva susceptible to parasitoids. Thus, a more detailed observation of mines, including the different development miner phases in Floscopa glabrata and Commelina diffusa will provide new information related to endoparasitoids in dipteran species

\section{Acknowledgments}

The authors would like to thank to Dr. Sergio Antonio Vanin (Museum of Zoology of University of São Paulo) for identifying the larva and Msc. Leornardo de Melo Versieux for identifying the species studied. The author Paula Maria Elbl would like to thank to The State of São Paulo Research Foundation (FAPESP) for her Master Degree scholarship; process number 06/58719-7. This work was also sponsored by the National Council of Technological and Scientific Development (CNPq). The authors would like to give a special thanks to Full Professor José Deodoro Trani Capocchi and MSc. Eng. Evaldo Toniolo Kubaski (Engineering School of University of Sao Paulo) for their contribution during the writing of this manuscript.

\section{References}

Abe, Y.; Takeuchi, T.; Tokumaru, S. \& Katama, J. 2005. Comparison of the suitability of three pest leafminers (Diptera: Agromyzidae) as hosts for the parasitoid Dacnusa sibirica (Hymenoptera: Braconidae). European Journal of Entomology 102: 805-807.

Abe, Y. 2006. Exploitation of the serpentine leafminer Liriomyza trifolii and tomato leafminer L. bryoniae (Diptera: Agromyzidae) by the parasitoid Gronotoma micromorpha (Hymenoptera: Eucoilidae). European Journal of Entomology 103: 55-59.
Almeida-Cortez, J.S. \& Melo-de-Pinna, G.F.A. 2006. Morphology and anatomy of a leaf mine in Vismia guianensis (Aubl.) Choisy (Clusiaceae) in a fragment of Brazilian Atlantic forest. Brazilian Journal of Biology 66: 759-763.

Berg, M.B. 1991. Larval food and feeding behavior. Pp. 136-168. In: Armitage, P.D., Cranston, P.S., Pinder L.C.V., (ed.). The Chironomidae: The Biology and Ecology of Non-Biting Midges. London, Chapman and Hall.

Bickel, D.J. 1982. Diptera. Pp. 563-599. In: Parker, S.P. (ed.) Synopsis and classification of living organisms. New York, McGraw-Hill.

Brown, W.L.Jr. 1982. Hymenoptera. Pp. 652-680. In: Parker, S.P. (ed.). Synopsis and classification of living organisms. New York, McGrawHill.

Faden, R.B. \& Hunt, D. R. 1991. The Classification of the Commelinaceae. Taxon. 40: 19-31.

Foster, A.S. 1950. Techniques for the study of venation patterns on the leaves of Angiosperms. Proceedings of the 7th International Congress of Botany, Stockholm: 586-587.

Hawkins, B.A. 1994. Pattern and process in host-parasitoid interactions. New York, Cambridge University Press.

Hering, E.M. 1951. Biology of the leaf miners. Berlin, Dr. W. Junk Gravenhage.

Hespenheide, H.A. 1991. Bionomics of Leaf-Mining Insects. Annual Review of Entomology 36: 535-560.

Jervis, M.A. \& Kidd, N.A.C. 1986. Host-feeding strategies in hymenopteran parasitoids. Biological Reviews 61: 395-434.

Johansen, D. 1940. Plant microtechnique. New York, McGrawn Hill book Co. Inc.

Labandeira, C.C. 1998. Early history of arthropod and vascular plant associations. Review of Earth and Planetary Sciences 26: 329-377.

Kraus, J. E.; Sousa, H. C.; Rezende, M. H.; Castro, N.M.; Vecchi, C. \& Luque, R. 1998. Astra blue and basic fucsin double staining of plant materials. Biotechnic \& histochemistry 73: 235-243.

Mani, M.S. 1964. Ecology of plant galls. The Hague, Dr. W. Junk Publishers.

Melo-de-Pinna, G.F.A.; Kraus, J.E. \& Menezes, N.L. 2002. Morphology and anatomy of leaf mine in Richterago riparia Roque (Asteraceae) in the campos rupestres of Serra do Cipó, Brazil. Brazilian Journal of Biology 62: 179-185.

Needham, J.G.; Frost, S.W. \& Tothill, D. 1928. Leaf-mining insects. Baltimore, The Williams \& Wilkens, Co.

Pott, V.J. \& Pott, A. 2000. Plantas aquáticas do Pantanal, Brasília, Embrapa.

Ruzin, S.E. 1999. Plant microtechnique and microscopy. New York, Blackwell Synergy, Oxford University Press.

Salvo, A. \& Valladares, G.R. 2007. Looks are important: parasitic assemblages of Agromyzid leafminers (Diptera) in relation to mine shape and contrast. Journal Animal Ecology 73: 494-505.

Santos, J.P.; Dal Soglio, F.K. \& Redaelli, L.R. 2006. Plantas hospedeiras de dípteros minadores em pomar de citros em Montenegro, RS. Arquivos do Instituto Biológico 73: 235-241.

Solereder, H. \& Meyer, F.J. 1929. Commelinaceae in Systematische Anatomie der Monokotyledonen. Heft IV: 129-155.

Stehr, F.W. 1991. Agromyzidae. Pp. 819-820. In: Stehr, F.W. (ed.) Immature Insects. Iowa, Kendall / Hunt Publishing Co. Dubuque.

Tran, D.H.; Ueno, T. \& Takagi, M. 2007 Comparison of the suitability of Liriomyza chinesis and L. trifolii (Diptera: Agromyzidae) as hosts for Neochrysocharis okazakii (Hymenoptera: Eulophidae). Biolological Control 41: 354-360.

Weis, A.E. \& Berenbaum, M.R. 1989. Herbivorous insects and green plants. In: Abrahamson, W.G. (ed.) Plant-animal interactions. New York, McGraw Hill-Book Co.

Xu, P.; Wan, Z.W.; Chen, X.X.; Liu, S. \& Feng, M.G. 2007. Immature morphology and development of Opius caricivorae (Hymenoptera: Braconidae), an endoparasitoid of the leafminer Liriomyza sativae (Diptera: Agromyzidae). Annals of Entomological Society America 100: $425-432$.

Versão eletrônica do artigo em www.scielo.br/abb e http://www.botanica.org.br/acta/ojs 